\title{
Colombian prisons as a core institution of authoritarian liberalism
}

\author{
Manuel Iturralde ${ }^{1}$
}

Published online: 12 September 2015

(C) The Author(s) 2015. This article is published with open access at Springerlink.com

\section{Introduction}

In the past two decades Colombia has seen a constant and dramatic rise in its imprisonment rates. ${ }^{1}$ In twenty years, between 1994 and 2014, the inmate population grew by $305 \%$ (from 1994 to 2004, an increase of $33.43 \%$; from 2004 to 20014, $78.96 \%$-See Table 1 and Chart 1). This expansion has further worsened the already precarious condition of those citizens deprived of their liberty by the Colombian State; and the term 'crisis' has become the cliché of choice used to describe the Colombian penitentiary system during the past three decades. One of the major failures of the Colombian judicial system during this period has been its negligence concerning the country's prisons, which are characterized by deficient infrastructure, overcrowding, violence and the persistent and nearly total violation of prisoners' human rights. Therefore, this 'crisis' is merely a euphemism used to describe a situation that has stretched out over decades.

From 1994 to 2011 the number of crimes reported by the Colombian National Police Force also rose significantly (by $136.3 \%$-See Chart 2), which could explain the significant increase in the number of inmates. However, this is not an entirely satisfactory explanation, due to the fact that the percentage of the increase of the prison population doubled (305\%) in comparison with the increase of crimes reported (See Charts 1 and 2).

\footnotetext{
${ }^{1}$ According to INPEC (National Bureau of Colombian Prisons) statistics, the average number of inmates during the eighties came to 28,000; the average number in the nineties was 38,391; from the year 2000 to 2014 (March) the average was 72,906. See, INPEC [25, 27, 32].
}

Manuel Iturralde

miturral@uniandes.edu.co

1 Law Department, Universidad de los Andes, Bogotá, Colombia 
Table 1 Prisons and inmate population in Colombia (1994-2013)

\begin{tabular}{|c|c|c|c|c|c|}
\hline Year & Total capacity & $\begin{array}{l}\text { Population } \\
\text { (annual average) }\end{array}$ & $\begin{array}{l}\text { Overcrowding } \\
\text { (annual average) }\end{array}$ & On remand & Sentenced \\
\hline 1994 & 26,709 & 29,343 & $9.9 \%$ & 15,860 & 13,483 \\
\hline 1995 & 27,822 & 31,690 & $14.9 \%$ & 15,492 & 16,468 \\
\hline 1996 & 28,332 & 38,063 & $34.3 \%$ & 17,817 & 20,246 \\
\hline 1997 & 29,239 & 41,404 & $41.6 \%$ & 19,227 & 22,177 \\
\hline 1998 & 33,009 & 43,259 & $31.1 \%$ & 20,014 & 23,245 \\
\hline 1999 & 33,090 & 46,322 & $40 \%$ & 19,731 & 26,591 \\
\hline 2000 & 35,969 & 49,816 & $38.5 \%$ & 20,326 & 29,490 \\
\hline 2001 & 40,037 & 52,181 & $30.3 \%$ & 21,420 & 30,761 \\
\hline 2002 & 44,373 & 51,276 & $15.6 \%$ & 21,199 & 30,077 \\
\hline 2003 & 46,399 & 58,894 & $26.9 \%$ & 25,271 & 33,623 \\
\hline 2004 & 48,916 & 66,474 & $35.9 \%$ & 28,751 & 37,723 \\
\hline 2005 & 49,763 & 69,365 & $39.4 \%$ & 28,611 & 40,754 \\
\hline 2006 & 52,115 & 62,906 & $20.7 \%$ & 21,992 & 40,914 \\
\hline 2007 & 52,504 & 61,543 & $17.2 \%$ & 20,280 & 41,263 \\
\hline 2008 & 53,672 & 67,388 & $25.5 \%$ & 23,195 & 44,144 \\
\hline 2009 & 55,042 & 76,471 & $38.9 \%$ & 25,619 & 50,852 \\
\hline 2010 & 56,970 & 79,730 & $40 \%$ & 25,102 & 54,628 \\
\hline 2011 & 75.620 & 100.451 & $32.8 \%$ & 27.320 & 73.131 \\
\hline 2012 & 75.726 & 109.378 & $44.55 \%$ & 34.571 & 79.313 \\
\hline 2013 & 76.066 & 120.032 & $57.8 \%$ & 37.052 & 82.980 \\
\hline 2014 (March) & 76.180 & 118.968 & $56.16 \%$ & 39.730 & 79.238 \\
\hline
\end{tabular}

Source: National Bureau of Colombian Prisons (INPEC) [28, 29, 32]

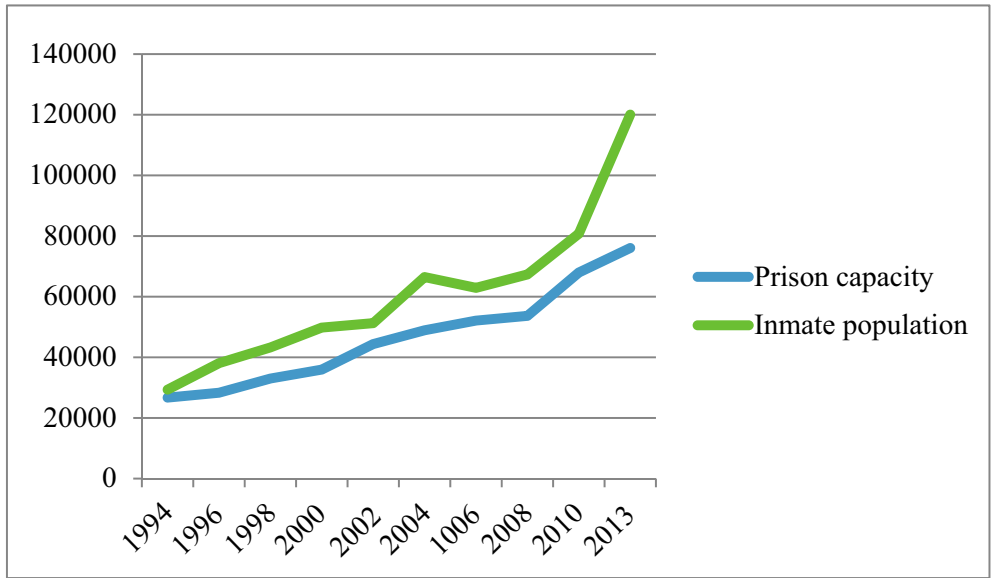

Chart 1 Prison capacity and inmate population 1994-2014 (March). Source: National Bureau of Colombian Prisons (INPEC) [28, 29, 32] 


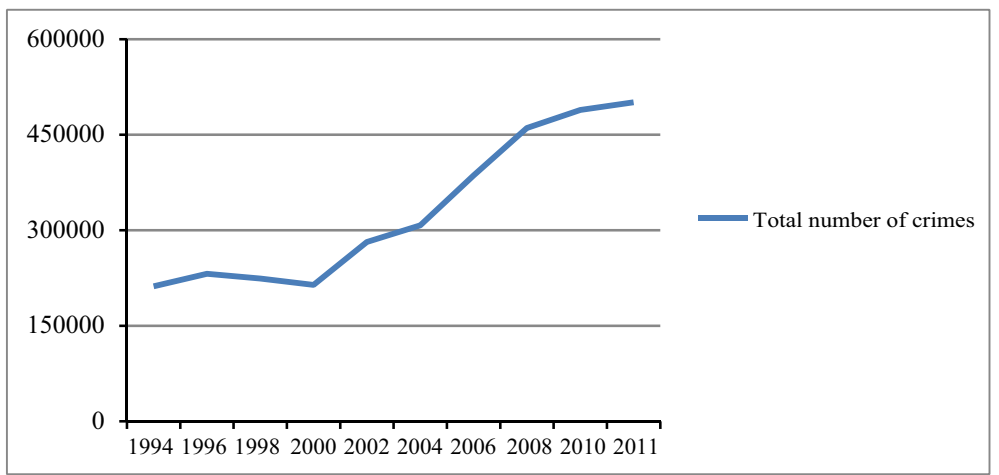

Chart 2 Crimes reported by the Colombian National Police Force (1994-2011). Source: Colombian National Police Force [7-9]

The tendency towards ever-increasing imprisonment rates -which is not necessarily directly related to the rising crime rate ${ }^{2}$ - has been taking place not only in Colombia, but worldwide, as well; in the Global North, in countries such as England and the United States, the inmate population has grown considerably, and their respective penitentiary systems have proven unable to fully confront the situation (as a result of the state's indifference or incompetence), which has, consequently, led to a dramatic decline in prisoners' living conditions [20:19]. Latin America is no exception: between 2000 and 2010 imprisonment rates rose 68 \% [1] (See Table 2; Chart 3).

The problem of incarceration in Colombia, which is similar to that in other countries, is neither passing nor confined behind prison walls; it affects Colombian society as a whole because it mirrors its problems and internal conflicts. Colombian prisons dramatically underscore how vast sectors within an exclusionary and unequal society are further marginalized through stigmatization and rejection as they are placed in the roles of dangerous delinquents. Prisons, in Colombia and elsewhere, also exemplify how modern societies prefer to face their structural problems and social instability by means of repressive criminal policies; thus further contributing to what Simon calls governing through crime [57, 58].

The feelings of fear and defenselessness that permeate many societies are channeled by governments into strategies which augment and intensify the tools and techniques for control and security. This combination of factors, especially during the past three decades, has given rise to a Culture of Control [20: 175] which affects the lives of every citizen and which inspires governmental policy at the global level in a wide diversity of countries, in the Global North as well as in the Global South. It may be inaccurate to state that international homogeneity exists for punishment; in fact, a wide variety of tendencies can be found worldwide- as authors such as Lacey [40, 41], Whitman [64], Lappi-Seppälä [42], Melossi et al. [43], Nelken [45, 46] and Sozzo [59] have pointed out. There is, however, in many countries both of the Global North and South a trend towards penal convergence [5: 438, 441], as witnessed by the overall growth of the inmate population brought about by increasingly harsh penal laws.

\footnotetext{
${ }^{2}$ For example, while imprisonment rates have quadrupled in the United States during the past three decades, crime rates have tended to go down during the past twenty years. In England, the inmate population has gone up considerably, by some $60 \%$ over the past three decades; however, crime rates have tended to go down since 1990 [See 20: 208-209].
} 
Table 2 Prison population per 100,000 inhabitants (and total inmate population) in Latin American countries (1992-2013)

\begin{tabular}{|c|c|c|c|c|c|c|c|}
\hline Country & $1992 / 1993$ & $1995 / 1996$ & $1998 / 1999$ & $2001 / 2002$ & $2004 / 2005$ & $2007 / 2008$ & $2011 / 2013$ \\
\hline Argentina & $\begin{array}{l}63 \\
(21,016)\end{array}$ & $\begin{array}{l}75 \\
(25,852)\end{array}$ & $\begin{array}{l}100 \\
(35,808)\end{array}$ & $\begin{array}{l}109 \\
(41,007)\end{array}$ & $\begin{array}{l}140 \\
(52,472)\end{array}$ & $\begin{array}{l}154 \\
(60,621)\end{array}$ & $\begin{array}{l}2011 \\
147 \\
(60,789)\end{array}$ \\
\hline Bolivia & N.D. & $\begin{array}{l}71 \\
(5412)\end{array}$ & $\begin{array}{l}86 \\
(6867)\end{array}$ & $\begin{array}{l}110 \\
(9145)\end{array}$ & $\begin{array}{l}79 \\
(7310)\end{array}$ & $\begin{array}{l}82 \\
(7682)\end{array}$ & $\begin{array}{l}2011 \\
112 \\
(11,516)\end{array}$ \\
\hline Brasil & $\begin{array}{l}74 \\
(114,377)\end{array}$ & $\begin{array}{l}92 \\
(148,760)\end{array}$ & $\begin{array}{l}102 \\
(170,602)\end{array}$ & $\begin{array}{l}133 \\
(233,859)\end{array}$ & $\begin{array}{l}183 \\
(336,358)\end{array}$ & $\begin{array}{l}220 \\
(422,590)\end{array}$ & $\begin{array}{l}2012 \\
276 \\
(549,577)\end{array}$ \\
\hline Chile & $\begin{array}{l}155 \\
(20,989)\end{array}$ & $\begin{array}{l}155 \\
(22,023)\end{array}$ & $\begin{array}{l}181 \\
(26,871)\end{array}$ & $\begin{array}{l}225 \\
(34,717)\end{array}$ & $\begin{array}{l}238 \\
(38,064)\end{array}$ & $\begin{array}{l}276 \\
(45,843)\end{array}$ & $\begin{array}{l}2013 \\
272 \\
(47,620)\end{array}$ \\
\hline Colombia & $\begin{array}{l}100 \\
(33,491)\end{array}$ & $\begin{array}{l}107 \\
(37,428)\end{array}$ & $\begin{array}{l}127 \\
(51,693)\end{array}$ & $\begin{array}{l}126 \\
(54,034)\end{array}$ & $\begin{array}{l}152 \\
(68,545)\end{array}$ & $\begin{array}{l}150 \\
(69,979)\end{array}$ & $\begin{array}{l}2013 \\
241 \\
(115,781)\end{array}$ \\
\hline Ecuador & $\begin{array}{l}74 \\
(7998)\end{array}$ & $\begin{array}{l}84 \\
(9646)\end{array}$ & $\begin{array}{l}78 \\
(9439)\end{array}$ & $\begin{array}{l}61 \\
(7859)\end{array}$ & $\begin{array}{l}86 \\
(11,358)\end{array}$ & $\begin{array}{l}126 \\
(17,065)\end{array}$ & $\begin{array}{l}2010 \\
86 \\
(11,800)\end{array}$ \\
\hline Mexico & $\begin{array}{l}98 \\
(85,712)\end{array}$ & $\begin{array}{l}102 \\
(93,574)\end{array}$ & $\begin{array}{l}133 \\
(128,902)\end{array}$ & $\begin{array}{l}164 \\
(165,687)\end{array}$ & $\begin{array}{l}183 \\
(193,889)\end{array}$ & $\begin{array}{l}193 \\
(212,841)\end{array}$ & $\begin{array}{l}2013 \\
209 \\
(242,754)\end{array}$ \\
\hline Nicaragua & $\begin{array}{l}85 \\
(3375)\end{array}$ & $\begin{array}{l}103 \\
(4586)\end{array}$ & $\begin{array}{l}134 \\
(6535)\end{array}$ & N.D. & N.D. & $\begin{array}{l}107 \\
(6060)\end{array}$ & $\begin{array}{l}2011 \\
122 \\
(7200)\end{array}$ \\
\hline Panama & $\begin{array}{l}178 \\
(4428)\end{array}$ & $\begin{array}{l}249 \\
(6607)\end{array}$ & $\begin{array}{l}300 \\
(8290)\end{array}$ & $\begin{array}{l}333 \\
(9643)\end{array}$ & $\begin{array}{l}353 \\
(11,292)\end{array}$ & $\begin{array}{l}295 \\
(10,036)\end{array}$ & $\begin{array}{l}2012 \\
392 \\
(14,238)\end{array}$ \\
\hline Paraguay & N.D. & $\begin{array}{l}60 \\
(2972)\end{array}$ & $\begin{array}{l}75 \\
(4088)\end{array}$ & N.D. & $\begin{array}{l}86 \\
(5063)\end{array}$ & $\begin{array}{l}95 \\
(5889)\end{array}$ & $\begin{array}{l}2009 \\
97 \\
(6300)\end{array}$ \\
\hline Peru & $\begin{array}{l}71 \\
(15,718)\end{array}$ & $\begin{array}{l}90 \\
(20,899)\end{array}$ & $\begin{array}{l}106 \\
(26,059)\end{array}$ & $\begin{array}{l}105 \\
(26,968)\end{array}$ & $\begin{array}{l}116 \\
(31,311)\end{array}$ & $\begin{array}{l}141 \\
(39,684)\end{array}$ & $\begin{array}{l}2012 \\
199 \\
(60,239)\end{array}$ \\
\hline Uruguay & $\begin{array}{l}97 \\
(3037)\end{array}$ & $\begin{array}{l}100 \\
(3192)\end{array}$ & $\begin{array}{l}121 \\
(3927)\end{array}$ & N.D. & N.D. & $\begin{array}{l}193 \\
(6947)\end{array}$ & $\begin{array}{l}2012 \\
279 \\
(9450)\end{array}$ \\
\hline Venezuela & $\begin{array}{l}111 \\
(23,200)\end{array}$ & $\begin{array}{l}102 \\
(22,791)\end{array}$ & $\begin{array}{l}97 \\
(22,914)\end{array}$ & $\begin{array}{l}77 \\
(19,368)\end{array}$ & $\begin{array}{l}74 \\
(19,853)\end{array}$ & $\begin{array}{l}79 \\
(22,000)\end{array}$ & $\begin{array}{l}2011 \\
169 \\
(50,000)\end{array}$ \\
\hline
\end{tabular}

*N.D. No data

Source: International Centre for Prison Studies (2013)

The study, therefore, of the 'crisis' in Colombia's prisons, as a paradigmatic example of a global tendency, cannot be approached from a reductionist viewpoint that attempts to be explained in its own terms. On the contrary, it must be based upon a wider perspective, one which includes understanding the penal system as the way state and society perceive crime and its respective forms of punishment. Punishment is not merely 


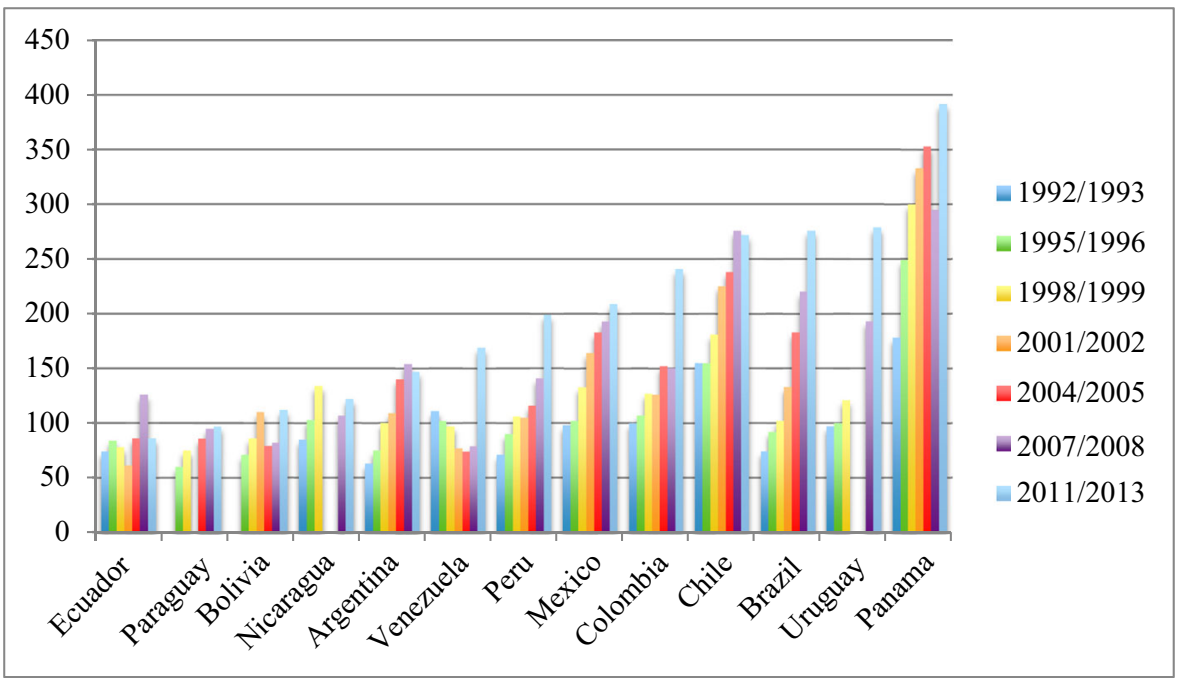

Chart 3 Imprisonment rates (per 100,000 inhabitants) in Latin America (1992-2013). Source: International Centre for Prison Studies [33]

the way delinquents are treated; it is an authentic social institution which helps to define, and which at the same time reflects, the nature of a given society, and the relationships and conflicts of which it is made up [18: 287]. Thus, the current management of prisons and the penal system provide a key to understanding the transformation of Colombian society, along with its conflicts, during the past three decades, as well as to how social and power relationships have led diverse administrations into marginalizing an extensive sector of the population with the argument that by doing so they are protecting society. From a sociological standpoint on punishment and prisons -both to be understood as complex social institutions-, this article aims to provide a critical diagnosis of Colombian prisons, and of their political and cultural uses and meanings in Colombian society over the past 30 years. Towards this end, in the first part of the article (made up of the first two sections) I will present a critical analysis, based mainly upon official statistics, of the major features and transformations in Colombian corrections facilities and in their inmate populations, and of the criminal policies which legitimize their workings and existence. In the second part (which is made up of the two following sections), by referring to aspects and changes in Colombian prisons, I will explain the political and cultural meanings and uses of prisons in contemporary Colombian society.

The central thesis of this essay is that prisons have been turned into core symbols and institutions of authoritarian liberalism. This refers to a form of government, which has consolidated in the past three decades to a great degree due to its overlapping with a neoliberal political economy, but that nevertheless may not be reduced to a worldwide expansion of neoliberalism -as some authors, like Wacquant [63], claim, since it predates the arrival of neoliberalism to Colombia and Latin America during the eighties, and has features and dynamics of its own [35, 36, 38]. Authoritarian liberalism as a form of government protects the interests of the status quo -even if violence must be used- by sacrificing the rights of society's poorest and most vulnerable groups (which in Colombia is half the population). This state-sponsored defense of the 
predominant powers in Colombia has created a conspicuously exclusionary and unequal society, which, in large part, justifies the use and expansion of the prison system as a reaction to feelings of fear and vengeance. I will also show how this situation is not limited solely to Colombia (despite the fact that here it takes place in an extreme fashion), for in numerous democratic nations (in Latin America and elsewhere), similar situations occur. Hence, I assess, particularly for the Colombian case, the thesis which claims that the globalization of the neoliberal economic and political model is accompanied by a specific punitive model that excludes the poorest social groups through the use of punishment with the aim of consolidating a new form of government [63: xviii]. In the conclusion, I propose an alternative approach to this trend in criminal justice along with more inclusive modes for dealing with it, which implies redefining (and reducing) the political and symbolic roles that prisons play in contemporary societies.

\section{Colombian prisons during the past three decades: a history of failure}

In 1989, overcrowding in Colombian prisons was not excessively high: 166 corrections facilities, with capacity for 26,307 inmates, held 26,715 prisoners, which came to a $1.55 \%$ overcrowding rate [6: 230-231]. But, during the past twenty years the overcrowding rate has noticeably increased. Whereas, during the first part of the nineties prison capacity had increased by 6000 places, during the same period the inmate population rose by 18,000: in just six years the overcrowding rate in prisons went from $10 \%$ (in 1993) to $40 \%$ (in 1999) [27].

Overcrowding tended to go down between the years 2000 and 2002 (from 38.5 to $15.6 \%$ ), and between 2005 and 2008 (from 39.4 to $25.5 \%$ ); this was due mainly to an increase in individual prison places (which climbed from 35,969 in 2000 to 53,672 in 2008 -an increase of $49.21 \%$ ), and not to a lower inmate population which has continued to go up year after year (from 49,816 in 2000 to 118,968 in 20014 -a growth of $138.8 \%$ ) (See Table 1, Charts 1 and 4). Nevertheless, the overcrowding rate has been considerably high in spite of the numerous variations; and, what is more worrisome, between 2010 and 2013 a large jump occurred when it reached $53.7 \% \%$ in

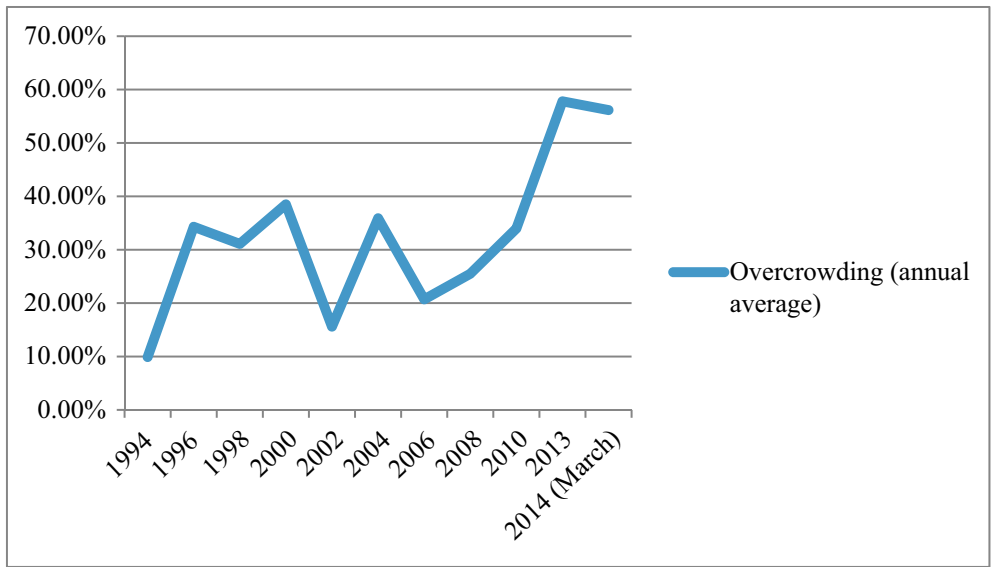

Chart 4 Percent of overcrowding in Colombian prisons (1994-2013). Source: INPEC [28] 
March 2013, a number that supersedes the historical peaks in 1997 (41.6 \%), 1999 (40\%) and 2005 (39.4\%) (See Table 1 and Chart 4).

Over the past two decades, excessive overcrowding, combined with the growing number of prisoners, has overwhelmed Colombia's obsolete corrections system and aggravated what have always been deficient prison conditions; at the same time, widespread chaos and violence have taken hold inside these facilities where the Colombian government has never really been in control [See 17].

Further proof of the inadequacy of Colombia's corrections infrastructure is the scarcity of education opportunities for inmates. In spite of the fact that education and work are two pillars of the prison system's rehabilitation scheme, Colombian prisons reveal just how far removed the State is from providing the minimum conditions needed to achieve a level of rehabilitation that would justify, at least within the rhetoric on prisons, their use as state sponsored institutions that guarantee the rule of law. By $1999,41 \%$ of the prison population was working in correctional facilities; in December $2005,34.45 \%$ had an occupation, and in September 2008, the percentage stood at $31.72 \%$ [27]. By December 2010 the percentage of inmates who had an occupation was reduced to $30 \%$ and in December, 2012 was further reduced to $27,8 \%$ [31]. The average percentage of the prison population that actively labored between 2002 and 2012 was $33 \%$. These figures show how inmates' access to rehabilitation programs has decreased over the last decade, to the point that not occupied inmates have become the majority (almost half) of the prison population in Colombia. (See Table 3, Chart 5).

A sizeable number of inmates occupy themselves with informal jobs, that is to say, with practically any kind of work -from selling food to cleaning floors- which prison authorities recognize as meriting reduced prison terms. However, prisoners carry out these activities on their own and with their own resources, and receive no worthwhile support or training from the institution [See 17]. In fact, according to a report from the National Office of the Comptroller (Contraloría General de la República), in 2006, the National Bureau of Colombian Prisons (INPEC) earmarked a mere $1.4 \%$ of its overall

Table 3 Index of occupations and education programs among the Colombian inmate population 2002-2012

\begin{tabular}{lllll}
\hline Month/year & Total population & Work & Study & No occupation \\
\hline December 2002 & 52,936 & $21,505(40.62 \%)$ & $17,420(32.9 \%)$ & $14,011(26.46 \%)$ \\
December 2003 & 62,281 & $21,461(34.45 \%)$ & $25,466(40.88 \%)$ & $15,354(24.65 \%)$ \\
December 2004 & 68,020 & $23,700(38.84 \%)$ & $27,748(40.79 \%)$ & $16,752(24.36 \%)$ \\
December 2005 & 66,289 & $23,027(34.45 \%)$ & $26,441(39.56 \%)$ & $17,361(25.97 \%)$ \\
December 2006 & 60,021 & $21,474(35.77 \%)$ & $26,755(44.5 \%)$ & $11,792(19.64 \%)$ \\
December 2007 & 63,603 & $21,463(33.74 \%)$ & $26,381(41.47 \%)$ & $15,759(24.77 \%)$ \\
September 2008 & 69,689 & $22,109(31.72 \%)$ & $29,916(38.62 \%)$ & $20,664(29.65 \%)$ \\
December 2010 & 84,444 & $25,389(30.06 \%)$ & $28,582(33.84 \%)$ & $30,473(36.08 \%)$ \\
December 2012 & 113,726 & $31,706(27,87 \%)$ & $38,042(33.45 \%)$ & $43,978(38,67 \%)$ \\
Average & 71,283 & $23,537(33 \%)$ & $27,083(37.99 \%)$ & $20,663(28.98 \%)$ \\
2002-2012 & & & & \\
\hline
\end{tabular}

Source: INPEC [27, 31] 


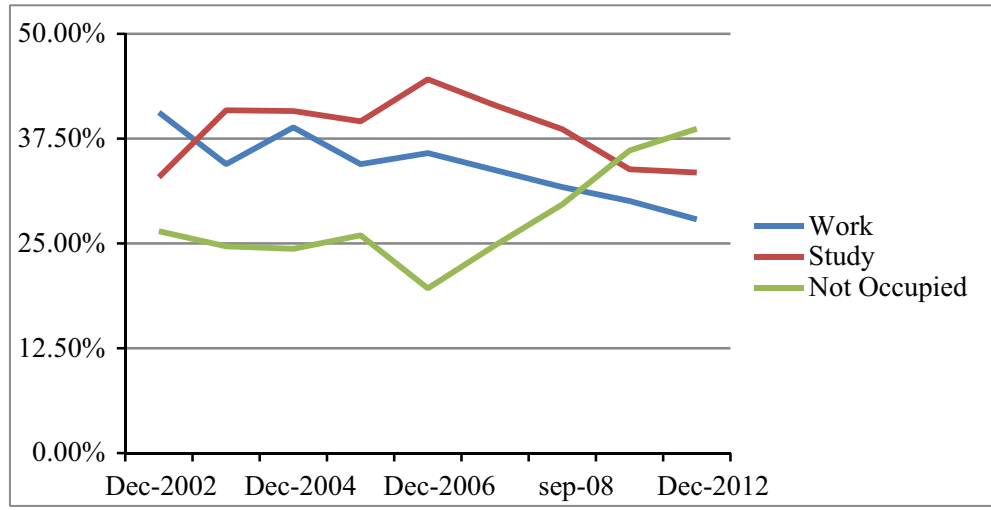

Chart 5 Inmate occupations (2002-2012). Source: INPEC [28, 31]

budget for rehabilitation programs (including education), which was even less than what had been assigned the year before [50: 4].

In so far as education is concerned, the other central pillar of rehabilitation, the panorama is similar: in 1999, $25 \%$ of the inmate population participated in educational programs; in December 2005, the percentage stood at $39.56 \%$, and in September 2008 it had reached $39.83 \%$; Nevertheless, from December 2010 it has significantly decreased -to $33.84 \%$ in that year and to $33.45 \%$ in December 2012. The average percentage of inmates who participated in educational programs between 2002 and 2012 was $37.99 \%$ $[25,27]$ (See Table 3, Chart 5). Educational programs are mainly focused on basic levels, primary education above all; whereas secondary and university education programs, which could have significant demand considering the educational profile of the prison population (as will be shown in the following section), are hardly available. Subsequently, between 2004 and 2007, only $1.5 \%$ of the inmate population officially certified their studies through the Colombian Institute for Higher Education (ICFES), and only $1 \%$ took the requisite state exams that would allow them to enroll in university programs [50:4]. As is often the case with occupational activities, educational programs serve primarily as the means to shorten prison stays rather than serving as the foundation for rehabilitating inmates so that they may become productive members of society.

The most worrying trend is the increasing number of prisoners who are neither working nor studying in the past decade (particularly from 2007), becoming the majority of the prison population in 2012: in 1999, $34 \%$ of the inmate population did not participate in any rehabilitation programs; the percentage of which dropped to $25.97 \%$ in 2005, and to $19.65 \%$ in December, 2005. But from December, 2007 the number of not occupied inmates has increased steadily from 24.77 to $38.67 \%$ in December 2012. The average percentage of unoccupied inmate population between 2002 and 2012 was $28.98 \%$ [25, 27, 31] (See Table 3, Chart 5).

Therefore, the statistics cited above clearly indicate that the rehabilitation programs proclaimed as institutional pillars of the penitentiary system from the time of its creation, have failed. Prison neither reforms nor educates. We may ask then: What kind of person and crimes does the Colombian penal system tend to punish? Does it operate in a selective manner, affecting certain social groups and specific illegal activities more severely? These questions will be answered in the following section. 


\section{Personal profiles and crimes committed by those who go to prison}

\section{The people}

The vast majority of Colombian inmates are male; the average rate has been between 93 and $94 \%$ of the total prison population during the past twenty years [6: 41;31]. In 1989 , inmates' ages fluctuated mainly between 16 and 30 years old $(57.7 \%) ; 28.7 \%$ of prisoners were between 31 and 40 years old; $9 \%$ between 41 and 50, and $4.5 \%$ were over age 50 [6: 73]. In 1999 and 2008 this tendency was reconfirmed: in 1999 most prisoners were between 18 and 29 years old (making up $43.81 \%$ of the total population); $34.42 \%$ of the inmates were between 30 and 39 years of age, and $16.51 \%$ were between 40 and 49 years old [25]. In 2008, $47 \%$ of the prison population was between 18 and 29 years old; $36.5 \%$ between 30 and $44 ; 13.5 \%$ between 45 and 50 ; and $3 \%$ over 60 [27]. In 2012, most of the prison population was between 30 and 54 years old $(51.73 \%)$, which indicates that, on average, such population is becoming older, even though it remains relatively young, especially taking into account that inmates between 19 and 29 years old make up $42.94 \%$ of the population [31]. These figures show that the inmate population in Colombia, even though is predominantly young, is becoming older; this may have to do to the increase of prisons sentences as a result of a more punitive penal policy. In fact, even though the majority of the prison population is sentenced to between 1 and 10 years (67.83\% of the prison population in April 2013) -a percentage that has increased over the last years (see Chart 8 ), there is also a notorious increase (178,93\%) of inmates serving long prisons sentences (more than 25 years) between 1999 and 2013 (see Charts 6 and 7).

In April, 2013, out of a total inmate population of 117,015, when grouped by gender, $92.42 \%$ were men and $7.58 \%$ were women. Even though there has been an increase of the proportion of women inmates (in $200894 \%$ were men and $6 \%$ women), this proportion has remained constant over time: between 1989 and 2008 there was practically no variation $[6: 41 ; 27]$.

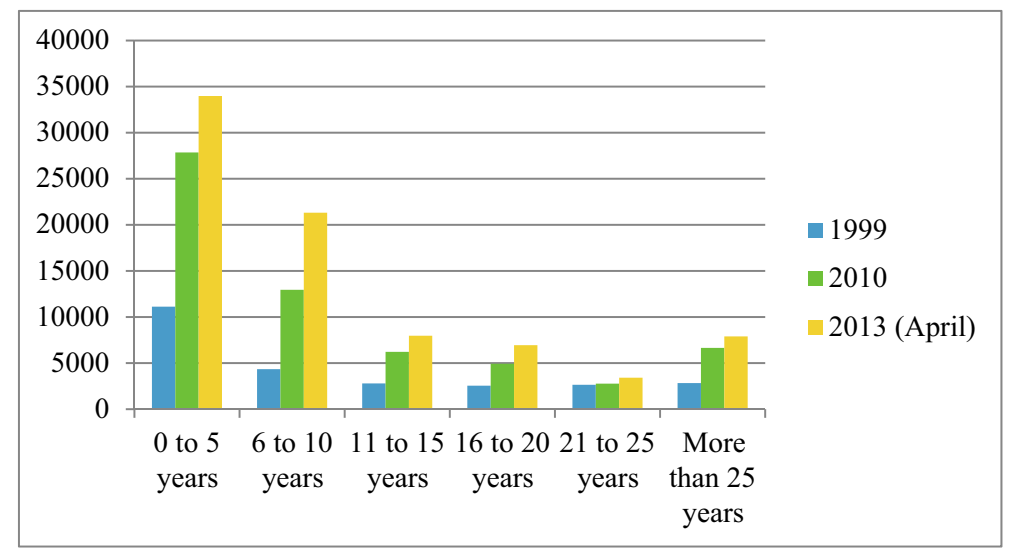

Chart 6 Length of inmates' prisons sentences (number of prisoners) (1999-2013-April). Source: INPEC $[26,30,31]$ 


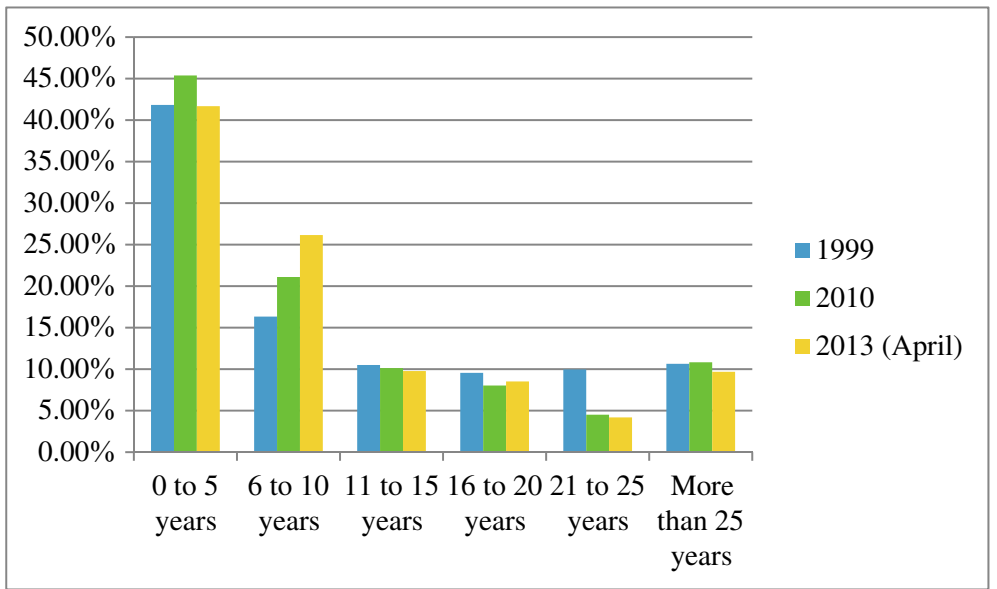

Chart 7 Length of inmates' prisons sentences (percentages) (1999-2013-April). Source: INPEC [26, 30, 31]

Where formal education among inmates is concerned, in 1989, 8.25\% had no education of any kind; $46.75 \%$ had attended (but not necessarily completed) some level of primary school, $34.5 \%$ had some secondary education and $6 \%$ had been enrolled in university or vocational institutions [6: 78]. By 1999 inmates' formal education levels had fallen even further: $12 \%$ had no formal education, $53 \%$ had been to primary school; $31 \%$ to secondary school and $3 \%$ had attended university or vocational schools [25]. In 2008, 5.85\% had no education, $42.43 \%$ had attended primary school, $48.16 \%$ secondary school, and $3.53 \%$ university or vocational school [27]. In 2013, $5.55 \%$ had no education, $40.29 \%$ had attended primary school, $54.15 \%$ secondary school, and $3.53 \%$ university or vocational school [31]. Although the percentage of the inmate population that has some kind of secondary schooling has gone up (from $34.5 \%$ in 1989 to $52.8 \%$ in 2013), during the past 20 years the proportion of prisoners who have not graduated from high school is still very high and has increased $(89.5 \%$ in $1989 ; 96.44 \%$ in 2008 , and $96.53 \%$ in 2013 ) (See Chart 8).

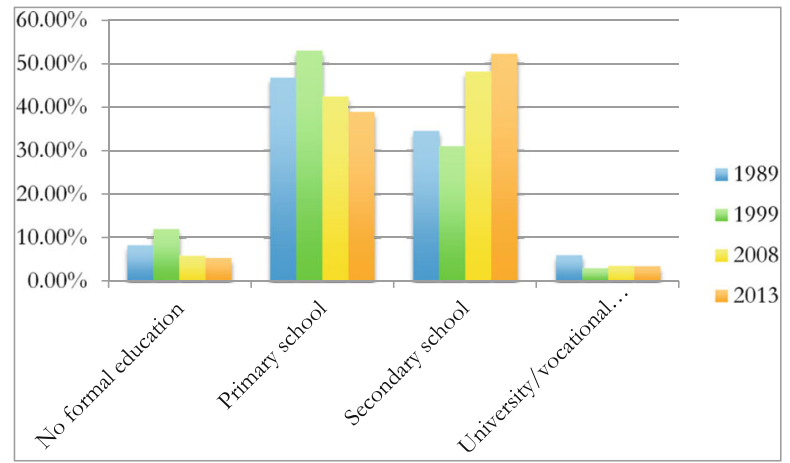

Chart 8 Inmate education levels (1989-2013). Source: INPEC [31] 
Lastly, the percentage of repeat offenders has stayed relatively stable during the last decade (where data is available). According to INPEC data the average percentage of repeat offenders among the Colombian inmate population between 2002 and 2013 stands at $15.02 \%$.

The foregoing data confirm a worldwide tendency regarding the demographic features of the prison population: in the overwhelming majority of contemporary capitalist societies, those who end up in prison are almost always young men, who often come from urban centers and marginalized environments, with scant education, and, as a rule, are unemployed or working in the informal economic sector [See 19: 1160-1161; 20: 90-93; 21: 5; 60, 61, 63, 66; for the case of Latin America, See 14, 15 , 39, 62].

\section{The crimes}

Crime statistics, prisoners' profiles and the crimes for which they are imprisoned are useful in understanding the selective manner in which the criminal justice system works, and for which the penitentiary provides the final phase and receptacle. Statistics serve to identify which crimes are the most likely to be prosecuted by the state and what kind of individuals will most probably end up in prison.

The following data focus on the years 1989, 1999, 2008 and 2013 and aim to illustrate, in broad terms, the changes and make up of certain patterns during this period. The crime figures compiled by the National Police Force, as well as the prison population, rose due to a variety of factors, including the escalation of the armed conflict in Colombia, the war on drugs, and the economic crisis that debilitated the country during the latter half of the nineteen-nineties [See Charts 9 and 10;2,4].

In 1977, the number of individuals imprisoned for homicide and aggravated assault came to $30 \%$ of the total inmate population, whereas the number of those held for crimes against property (mainly theft and grand larceny) made up $45.93 \%$, and those imprisoned for drug related offenses, 6.91\% [6: 84] (See Chart 11).

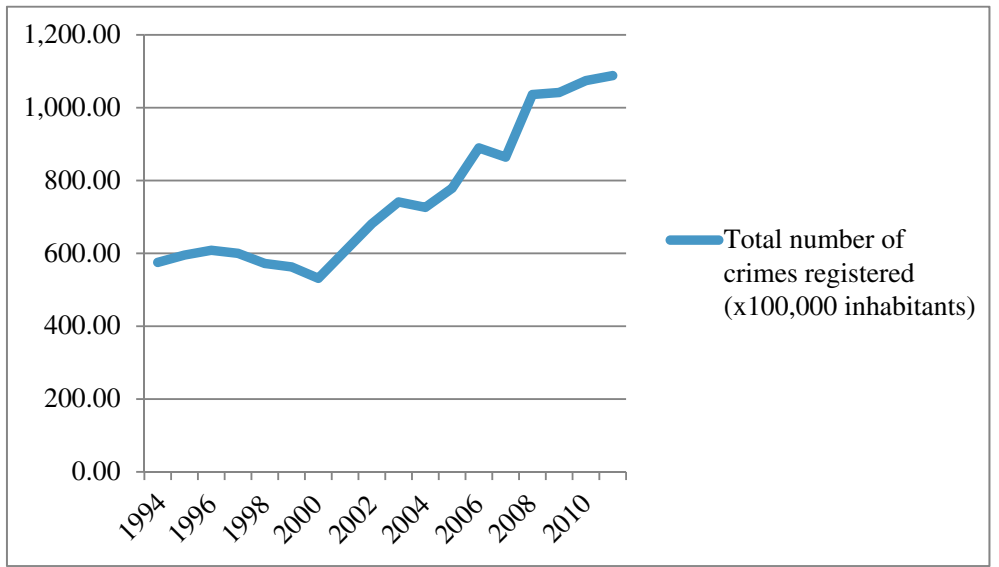

Chart 9 Total number of crimes reported per 100,000 inhabitants (1994-2011). Source: Colombian National Police Force [9] 


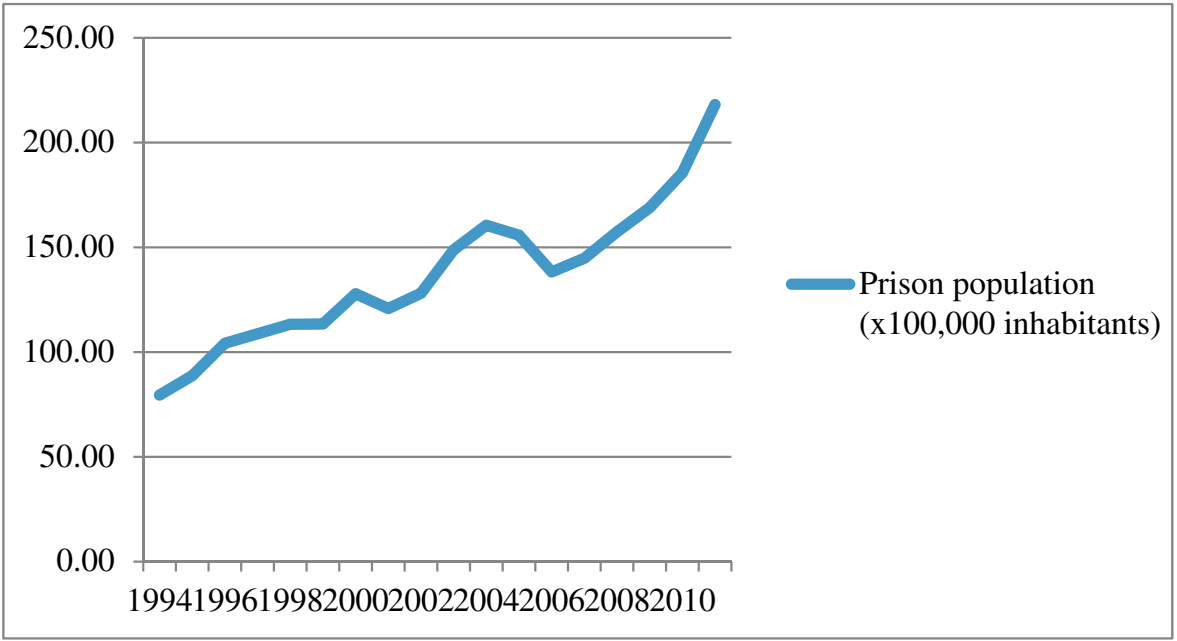

Chart 10 Prison population per 100,000 inhabitants (1994-2011). Source: INPEC [30]

By $1989,33.75 \%$ of the inmate population had been imprisoned for crimes against property and $30.75 \%$ for homicide and aggravated assault; $1.5 \%$ was being held on a combination of both types of crime. Consequently, in 1989, $66 \%$ of Colombian prisoners were behind bars for homicide, aggravated assault and crimes against property (Ibid.: 83, 84). Drug-trafficking accounted for $15.5 \%$, followed by crimes against state security forces (such as terrorism and related offenses, and the illegal possession of weapons) at $3.25 \%$; sexual assaults made up $2.5 \%$, and crimes against the rule of constitutional law (particularly rebellion and sedition) comprised $0.25 \%$ of the total (Ibid.: 87) (See Chart 11).

In December, 1999, the majority of prisoners in Colombian corrections facilities had been accused or sentenced for homicide, aggravated assault (31.09\%), or crimes against property $(28.59 \%$ ), which came to a combined total of $59.68 \%$ [27]. Next, were those crimes related to drug-trafficking $(10.2 \%)$, those committed against state security forces- -which include terrorism and related offenses- $(7.08 \%)$, sexual assaults (5.45\%), crimes against individual liberty -mainly kidnapping$(5.33 \%)$, and crimes against the rule of constitutional law -especially, rebellion- $(2.33 \%)$. (Ibid.) (See Chart 11).

In 2008, homicides and aggravated assault along with crimes against property continued to rank first and second at $26.66 \%$, and $24.82 \%$ of the total, respectively. Subsequently, when added together they represented more than half $(51.48 \%)$ of all crimes that had been committed by inmates in Colombia in that year [27]. The list continued with drug-trafficking (17.18\%), sexual assault $(9.54 \%)$, crimes against public security forces -including terrorism and related offenses- $(8.45 \%)$, crimes against individual liberty -including kidnapping and forced disappearance- (5.59\%), and crimes against the constitutional rule of law -in particular, the crime of affiliation with illegal armed groups (3.03\%) [27] (See Chart 11).

By April 2013, the same pattern continued -crimes against property (22.16\%) together with homicide and assault $(17.34 \%)$ made up the majority of crimes 

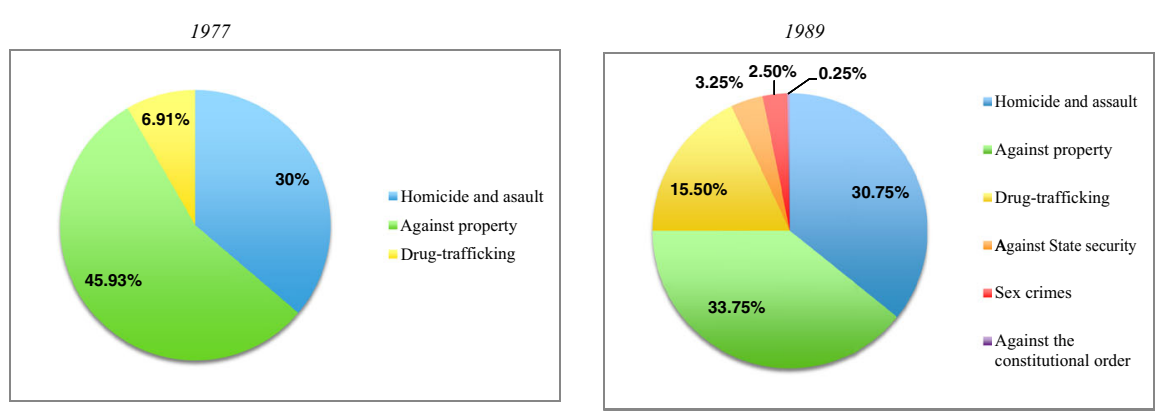

1999

2008
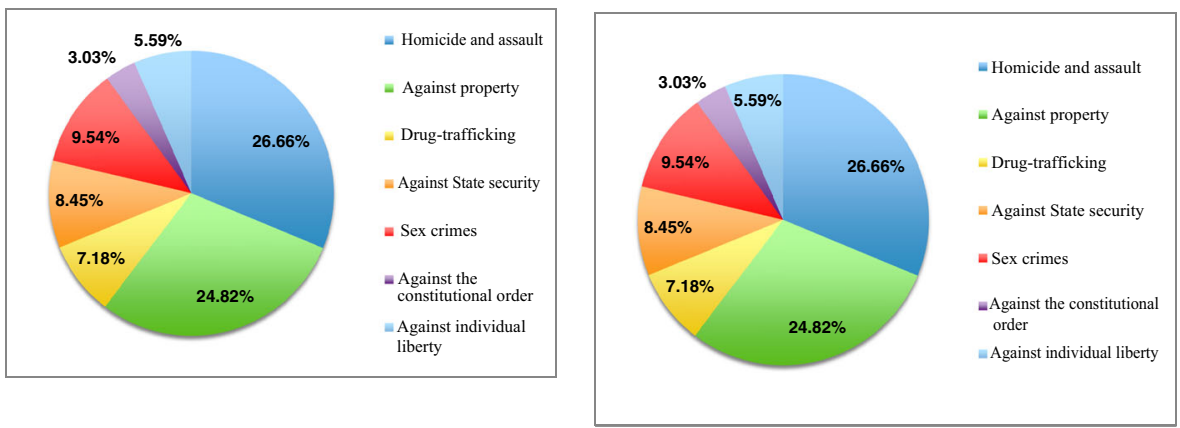

2013(April)

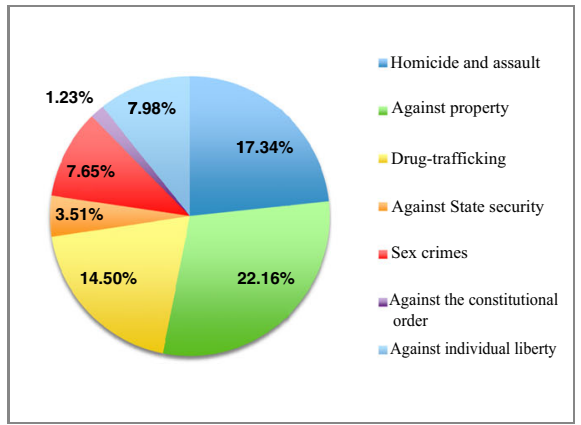

Chart 11 Percentage break-down of crimes committed by Colombian prisoners (1977-2013). Source: Colombian Ministry of Justice [6], INPEC [27, 31]

that ended up in prison $(39,50 \%)$, even though is worth noting that they no longer make up more than half of crimes. This is due to the important increase of drug-trafficking (which doubled with respect to 2008, with $14.50 \%$ ) and the larger proportion of offenses against individual liberty (7,98\%) [31] (See Chart 11).

As the abovementioned numbers reveal, starting in 1989 the proportion of inmates being held for homicide and assault as well as for drug-trafficking and terrorism went up conspicuously as a result of the country's armed conflict and the war on drugs, most notably against the Medellín cartel -from the latter part of the eighties until the first part 
of the nineties- a group notorious for violent and terrorist acts, and which was in the throes of its demise [36].

The growth of cocaine-trafficking has also intensified the armed conflict in Colombia as it provides immense capital resources which both the guerrilla and paramilitary militias use to procure arms for their troops, to battle one another and to maintain control over most of the coca growing regions in the country [See 4, 48, 54]. On the basis of the foregoing, it can be concluded that, in general terms, the intensification of violence and armed conflict coupled with the social and economic crisis that held sway during the decade of the nineties is reflected in Colombia's prison statistics, made up primarily of individuals indicted on and sentenced for crimes related to these calamities (crimes against property, homicide and aggravated assault, drug-trafficking and offenses against law enforcement).

The abovementioned data, which cover three different decades, reveal the fact that those imprisoned for homicide and aggravated assault, as well as for crimes against property, constantly comprise the largest portion of the Colombian inmate population (between 39.50 and $75 \%$ ). These categories are persistently followed by that which includes individuals accused of or sentenced for drug-trafficking (nearly $15 \%$ of the total inmate population), whose numbers doubled during the eighties -precisely when all-out war was declared on drugs- going from $6.91 \%$ of the total inmate population in 1977 to $15.5 \%$ in 1989, and again between 2008 and 2013, and which rose as a consequence of the repressive criminal justice policy upon which the state instituted its war on drugs, organized crime and the various illegal militias operating within the country [See 36]. It is also worth noting the significant increase of inmate held for sex crimes (which increased from $2.50 \%$ in 1989 to $7,65 \%$ in 2013 -the proportion trebled). Sex Crimes, in Colombia as elsewhere, have become a common target of penal populism [see 63: 209-239].

\section{The selectivity of the Colombian penal system and its relation to authoritarian liberalism}

On the basis of the statistics analyzed in the section above, it may be concluded that the Colombian inmate population has not significantly varied during the past three decades, neither its basic features: it is a relatively young population, overwhelmingly masculine, with scant education and unemployed or working at low-paying jobs before entering prison. Hence, it is apparent that the majority of the inmate population comes from marginalized sectors of Colombian society, where high levels of exclusion and poverty prevail.

Government policies directed towards that part of the populace deemed delinquent, which Feeley and Simon [16] label as the New Penology, aim not to reduce crime and eliminate its causes, but rather to manage and control social groups looked upon as problematic. Additionally, this approach to government has tended to be associated during the past two decades, in the Global North as well as in the Global South, with the neoliberal agenda. That is to say, it is based upon the free market and deregulation of the economy, along with the 
downsizing of the welfare state which provides social benefits to marginal social sectors, and the broadening of the prison state, which through a system of punishment, maintains control over these same sectors [63: xviii]. ${ }^{3}$

Some authors, particularly from the Global North, as Lacey [41: 789], suspect that, since Latin American countries are more economically dependent upon and share closer political ties with the United States, they are probably more susceptible to being pressed into implementing the same corrections policies as those in use in the United States. More detailed research on particular Latin American countries, such as Sozzo's analysis of the Argentinian case [59], show that, even though the influence of neoliberalism in political, cultural and economic aspects of Latin American societies is undeniable, the features and transformation of their crime control fields respond to the particular and local dynamics of each society, rather than the influence or pressure exerted by the United States.

Furthermore, the last two decades have witnessed important transformations in Latin America, particularly in the political landscape, the most important being the political realignment of Latin American countries between left and right. Venezuela, Bolivia, Ecuador, and Nicaragua are undergoing intense political processes under the lead of leftist governments, which, at least at the discursive level, defend socialism in radical terms. On the other hand, countries like Colombia, México, Perú, and El Salvador have been led mostly by right-wing governments with a neoliberal tendency and a with a political and economic interest in having close ties with the United States. At the centre of the political spectrum there are countries like Brazil, Argentina, Uruguay, and Chile that have been ruled by leftist governments that have accepted market capitalism rules and principles as part of their political and economic agenda [37].

Considering all these important transformations, it is very likely that crime control fields have undergone important changes in countries like Venezuela, Bolivia, Ecuador, and Nicaragua, which are experiencing intense social and political conflicts that affect violence and crime rates, ${ }^{4}$ as well as penal policies and imprisonment rates. Actually, in many of the countries that are undertaking structural leftist reforms, imprisonment rates have increased, even though official data has become hard to get in many of these (like Venezuela, Ecuador, Nicaragua, and Bolivia). ${ }^{5}$

Even if most of Latin American countries share a common history and display cultural, economic, political and social similarities, they also have their own historical trajectories, which merit a detailed and nuanced analysis in order to establish resemblances as well as differences. Thus, compared and case study analyses on Latin

\footnotetext{
${ }^{3}$ Considerable discussion is taking place in the fields of criminology and sociology on the neoliberal state and its relationship to highly punitive and exclusionary corrections systems. Loïc Wacquant's book, Punishing the Poor: the Neoliberal Government of Social Insecurity [63] has provoked international debate on the subject. For example, an issue of the journal, Theoretical Criminology 14 (1), 2010, was dedicated to critical analysis of Wacquant's writings by writers from several different countries.

${ }^{4}$ Venezuela is a case in point. The murder rate has increased from 8 per 100,000 inhabitants in 1996, to 33 in 2000, 44 in 2003, 45 in 2006, and 79 in 2013 (the third highest in the world after Honduras and El Salvador). Between 1998 (when Chávez rose to power) and 2013, the murder rate in Venezuela quadrupled [47].

${ }^{5}$ Since the rise of Chavismo, the imprisonment rate also increased notably, from 97 inmates per 100,000 inhabitants in 1998, to 169 in 2011 -the latest official data available. In Nicaragua it increased from 85 in 1992 to 119 in 2007; in Ecuador, from 75 in 1992 to 127 in 2007; in Uruguay from 100 in 1992 to 257 in 2010; in Brazil from 107 in 1995 to 253 in 2010; in Argentina from 62 in 1992 to 153 in 2011; in Bolivia from 69 in 1996 to 92 in 2010 [see Table 2 and 33].
} 
American crime control fields ${ }^{6}$ are needed in order to assess the similarities of these fields (such as high crime -and particularly homicide- rates, increasing imprisonment rates, the hardening of criminal policies), how they came into being, their connections, as well as an explanation of their differences and divergent trajectories [37].

For the same reasons, though it may be reasonable to say that there is a certain drift towards penal convergence -and a harsh one, in many of the Latin American countries, regardless their political leaning to the right or left, there remains the task to explain to which degree such convergence is due to shared or different political and economic processes, or maybe to a combination of both. Regarding the global debate on the expansion of neoliberalism, the previous thoughts should warn us against the notion that, because of the influence of neoliberalism in political, cultural and economic aspects of Latin American societies, the features and transformations of their crime control fields respond exclusively or mainly to the influence or pressure exerted by neoliberal policies and doxa-US style.

Such caution is of special interest for the analysis of the Colombian case, for Colombia has had close political and economic ties to the United States, something that is evident in the configuration of the Colombian crime control field during the last three decades, in great measure due to the US led war against drugs [36]. Thus, it is not surprising that neoliberal technologies and discourses regarding crime control have influenced the Colombian crime control field [35-38, 52, 53, 56]. But, at the same time, one should bear in mind that Colombia, like every other Latin American country, has its own historical trajectory, and that the configuration of its crime control field, even though influenced by neoliberalism and close cooperation with the United States, predates it and presents its own features and processes.

Elsewhere $[35,36,38]$ I have used the term authoritarian liberalism as a concept that synthetizes the main features of the Colombian crime control field during the second half of the Twentieth century and the first two decades of the Twentieth First century. These basically point to the intensive use of punishment discourses and technologies to uphold, through violent means, a highly exclusive political and economic order to the benefit of elite groups of Colombian society. Although this may be regarded as a longlasting feature of the Colombian crime control field, authoritarian liberalism strategies, discourses and practices have changed over the years and have not been left untouched by the changes experienced by an increasingly globalized world.

Authoritarian liberalism has changed and adapted to different political, economic, and social circumstances throughout late modernity, just as the Colombian political system and society have undergone fundamental transformations. Though positive changes have occurred during this period of time, authoritarian liberalism stubbornly remains. Governments of different political persuasions, be they conservative or liberal, have resorted insistently to punishment and penal institutions to defend the establishment from what it perceives as threats to its interests, and even to its very existence. Nevertheless, the politics of penal institutions have responded through time to different social, economic, and political contexts, as well as framing different enemies. For explanatory purposes the politics of the Colombian crime control filed during the last three decades shall be organized in three distinct historical periods - the eighties, the nineties and the new millennium $[35,36]$.

${ }^{6}$ Sozzo's analysis of the Argentinian case [59] is a good example. 
The eighties in Colombia were marked by the war against drugs. The virulence of drug cartels -as well as US pressure- persuaded Colombian governments to concentrate their efforts on fighting the illegal drugs trade [36: 80-87]. The Colombian and US governments regarded narcotrafficking as a serious criminal problem that also threatened the national security of both countries. According to such a view, ruthless criminal organizations were the cause of the drugs problem and they had to be neutralized through repressive means.

This interpretation of narcotrafficking as both a criminal issue and a matter of national security, led to the war on drugs rhetoric, and the consequent conflation of penal and military technologies to fight it. The crime control field was the site where both techniques blended, resulting in a highly repressive penal system where the subjugation of the enemy, rather than the establishment of penal responsibility under the rule of law, was the main objective. Nevertheless, most of the people who ended up in prison under drug trafficking offences, were the rank and file of drug cartels or minor scale dealers, mostly young men from urban ghettos, hardly connected to drug kingpins, and who most of the times resorted to drug dealing as a way of survival in an informal market.

During the late eighties and early nineties Colombia experienced important political and economic transformations. On the one hand, legal and constitutional reforms, spearheaded by the 1991 Constitution, led to the strengthening of democratic institutions and the rule of law. On the other hand, the Barco (1986-1990) and Gaviria (19901994) administrations undertook economic reforms that liberalized the Colombian economy and placed it in the sphere of globalization and neoliberalism. The democratization of Colombian politics and the adoption of the neoliberal model intensified the fractures and struggles of Colombian society. For one thing, alternative political parties and social movements that entered the political scene and clamored for their rights, enshrined in the new Constitution, threatened the political hegemony, particularly of local and regional elites. For another, the new economic model mainly benefited the upper classes while excluding the most vulnerable and marginalized social groups, which in Colombia make up almost half of the population. Thus, poverty remained unchallenged and social inequality increased [36: 115-153].

During the last two decades the Andrés Pastrana (1998-2002), Álvaro Uribe (20022010) and Juan Manuel Santos (2010-2014) administrations have embraced neoliberalism, though with different political and ideological leanings, as the prevailing political and economic model of the new global order. Furthermore, they may be seen as the peak in the development of such a model in Colombia's late modern history.

Pastrana's Plan Colombia to fight narcotrafficking, which included drug cartels, guerrillas and paramilitaries [36: 179-227], Uribe's Democratic Security to defeat the guerrillas, narcotrafficking and terrorism (ibid: 229-304), and Santos Democratic Prosperity, as he called his plan to consolidate the previous government's achievements on security (while reaching for peace and the post-conflict), though supposed to be democratic in the sense of protecting all citizens without distinction, are actually different policies with a similar aim: protecting investment, wealth, and economic growth, which mainly favor a minority of the population.

Even though Santos political discourse is much more liberal than Uribe's, particularly regarding the armed conflict and its causes (Santos, supported by the Liberal Party, claims to represent the more progressive and pragmatic stance of a urban elite, opposed 
to the conservative and authoritarian ideology that sits better with the rural elites that Uribe represents), his security and penal polices are actually very similar to those he supported when he was Uribe's Minister of Defense. Besides the armed conflict, the Uribe and Santos administrations have stressed the need to fight and prevent crime especially in the main cities, where common crime is a big public concern. For instance, and despite iron-fisted policies to confront it, robbery (particularly of mobile phones) has increased over the years (see Chart 12). Nevertheless, murder rates in Colombia, even though they are still high for international standards, and remain among the highest in Latin America, have tended to decrease during the last decade (see Chart 13).

Both the Uribe and Santos administrations have used very similar measures, which rely on zero tolerance and the hardening of the penal system through the criminalization of conducts, the increase of prisons sentences, and the reduction of penal benefits, particularly access to alternative measures to prison, such as probation and parole, house detention, and electronic surveillance.

Regarding law and order (seguridad ciudadana) policies, the Uribe government passed to Congress two main proposals, which became Law 890 of 2004 and Law 1142 of 2007. Law 890 of 2004 raised minimum sentences by one third and maximum sentences by half for all kinds of legal offences. Thus, the maximum prison sentence in Colombia went from 40 to 50 years, and to 60 years for multiple crimes. Law 1142 of 2007 (Ley de Convivencia y Seguridad Ciudadana) granted greater flexibility in determining what constituted sufficient grounds for preventive detention. All that may be necessary is for the presiding judge to take into account the gravity (gravedad) and means (modalidad) by which the punishable conduct was carried out when determining the presumptive danger of the accused, independent of any extenuating circumstances or of the defendant's profile and background [24: 245].

This law also restricted the possibility of substituting prison detention for other forms of detention, such as house arrest, with the argument that the 21 offences for which such alternatives were prohibited (including among others domestic violence, theft and grand larceny, and fraud) "gravely affected the foundations of coexistence and public safety" [24: 239-240]. Similarly, Law 1098 of 2006 declared that for any person accused of committing sexual crimes against a minor, the only detention measure permitted would be that of preventive imprisonment. The same measure was included in Law 1474 of 2001 (the Anticorruption Statute) to be applied to a number of offences,

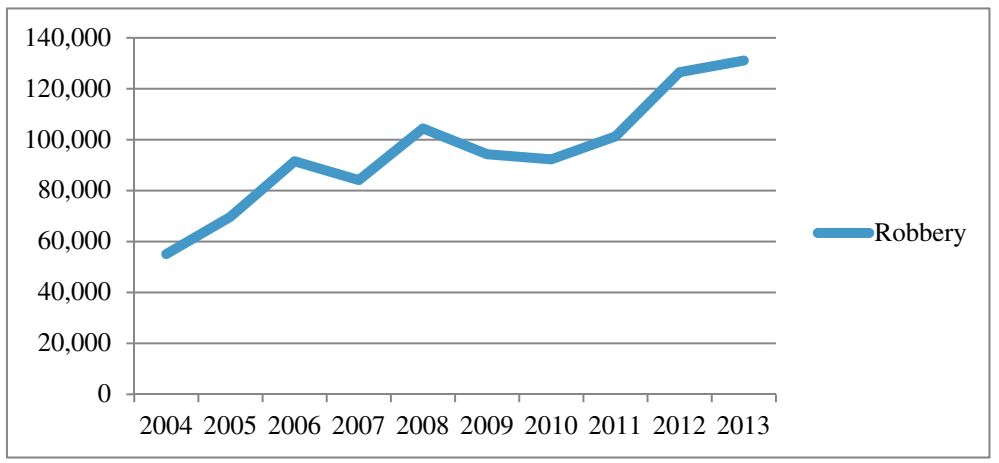

Chart 12 Reported Robbery Acts 2004-2013. Source: Ministry of Defence [44] 


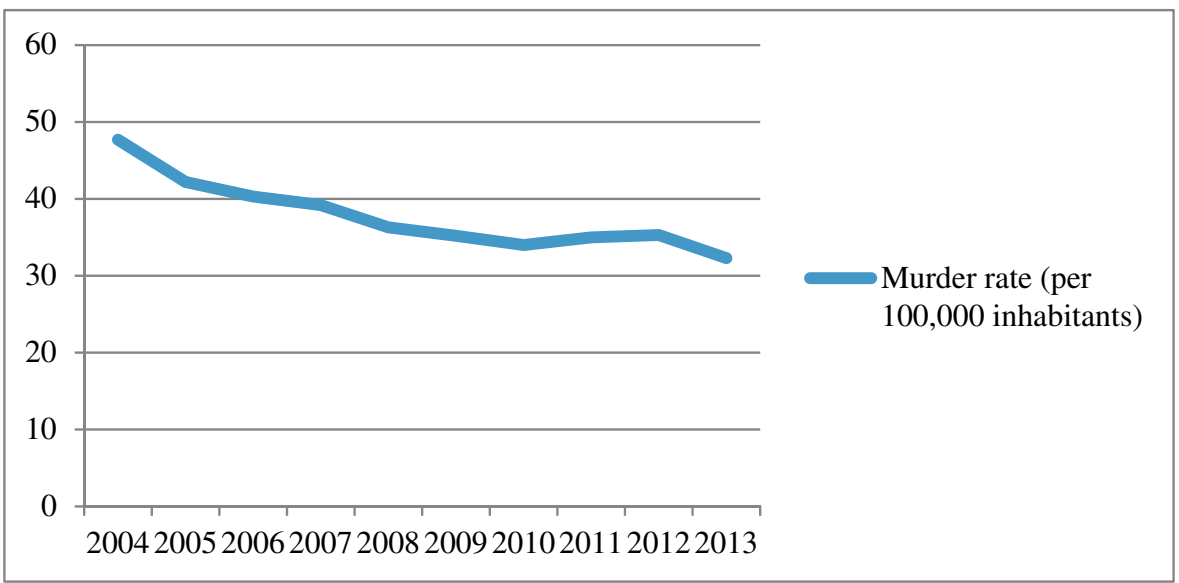

Chart 13 Murder rates per 100,000 inhabitants (2004-2013). Source: Ministry of Defence [44]

particularly those related to public administration. Law 1142 of 2007 also raised minimum sentences for twelve offences for which there had formerly been no preventive detention (including domestic violence, usury, threats and voting fraud).

As to Santos, after taking office in 2010, he claimed that his criminal and security policies would make a special emphasis on fighting urban common criminality, which was a main concern of urban voters, whose perception was that security levels were decreasing in the main cities, especially in regards to crimes against property and personal integrity (robbery, assault, injuries). Thus, the Santos government passed a law through Congress, which became Law 1453 of 2011 (Ley de Seguridad Ciudadana).

Following on the steps of Law 1142 of 2007, this statute also eased the requirements to impose prison detention and limited the access to penal benefits for several offences and for individuals with previous convictions. For instance, sex offenders, people convicted for drug related offences, aggravated conspiracy to commit a crime, terrorism, illegal possession of weapons, and money laundering, were completely excluded from parole (they would have to serve the full prison sentence). Simultaneously, the law established that parole could be granted only after serving two thirds of the prison sentence, instead of the three fifths previously established, which means longer periods of incarceration for all the sentenced population.

According to INPEC, between June 2011 (when the law was enacted) and February 2014, the prison population under Law 1453 of 2011 increased $13.4 \%$ (5632 inmates), mainly for drug related offences (2701 inmates) and illegal possession of weapons (2457 inmates) (INPEC [32]). According to a report by the Grupo de Derecho de Interés Público (Public Interest Law Group) -G-DIP, of the Law Department of Universidad de los Andes, the changes introduced by Law 1453 of 2011 meant that approximately $21 \%$ of the prison population $(25,058$ inmates $)$ sentenced for four different types of offences, would have to serve their full prison sentences, for they were excluded from parole and electronic surveillance. (G-DIP 2013).

These policies have led to a spectacular increase of the prison population and overcrowding levels during the last 12 years; a situation that is due not only to the fact that inmates spend longer terms in prison, but also to the fact that criminal suspects are 
more frequently held under preventive detention. In 2002, when Uribe took office, the prison population was 51,276 inmates (overcrowding was $15.6 \%$ ); by the end of Uribe government, the prison population was 79.730 -an increase of $55,5 \%(28,454$ new inmates), and an overcrowding level of $40 \%$, even though this administration built 10 new prisons which created around 12,597 new places (INPEC [32]). After four years of the Santos administration, the Colombian prison population is made of 118,968 inmates, with an historic peak in the overcrowding level of $56.16 \%$. Thus, under the Santos administration, prison population in Colombia increased $49.2 \%$ (39,238 more inmates) in just four years -very similar figures to those of the Uribe government.

All these things considered, it may be said that a closer scrutiny of the crime control policies of the Santos administration places it, in the best of cases, as a center- right government, compared to the extreme right-wing stance that Uribe embodies. Therefore, authoritarian liberalism, though it has undergone important changes over the last twenty years, is still a key feature of the Colombian crime control field and has expanded its scope for its rhetoric and methods are no longer restricted to fighting organized crime and illegal armed groups but also common urban criminality, under a zero tolerance stance akin to that imposed in other countries with a neoliberal political economy.

In the Colombian case, it may be claimed that the establishment of a political economy with a neoliberal leaning during the last 25 years has had a negative impact on social and economic equality and its crime control field, which has become even more punitive and exclusionary, particularly towards the urban poor young males, who have become a prime target of law and order policies [13, 35, 36, 38, 51-53]. The social and political policies, as well as the neoliberal state models that have tended to take hold in Colombia and significant parts of Latin America with the aid of hegemonic capitalistic globalization, have heightened exclusion and reduced opportunities for specific social groups, particularly for the very poor, who are the most vulnerable.

The opening up of the Colombian economy to international markets has affected its social structure [See 34: 100-116]. The impact of these policies, which were instituted during the nineties, is very telling: the country's political and economic elite has benefitted from market liberalization, whereas poverty, inequality, social instability, and economic crisis have hit the most vulnerable social classes the hardest -precisely those social groups who are excluded from financial and labor markets, as well as from public assistance programs [See 2].

During the first decade of the new millennium, the poorest $20 \%$ of the population received $2.5 \%$ of national income, whereas $20 \%$ of the richest received $61 \%$ [65]. Out of a total population of 41.2 million inhabitants (10.3 million of whom lived in rural areas), 2313 individuals (around $1.08 \%$ of the total number of property owners) possessed $53 \%$ of rural land [49: 16], and some 300 stockholders own $74 \%$ of shares traded on the Colombian stock market [3]; the ten largest companies in the country consumed $75 \%$ of financial market resources, which constitutes a Gini equity coefficient (which measures the concentration of equity ownership) of 0.93 [49: 17]. Inequality, which has always been pronounced in Colombia, has gone up even more during the recent past: between 2002 and 2005, the percentage of the national income for the poorest $40 \%$ fell from 12.3 to $12.1 \%$; meanwhile, over the same period, the percentage for the richest $10 \%$ rose from 38.8 to $41 \%$ [3]. 
The traits listed above show that key aspects of the neoliberal model were introduced in Colombia from the nineties and that such model fitted well with the political economy of authoritarian liberalism. The neoliberal agenda, like authoritarian liberalism, pursues the development of free markets and protects financial capital by implementing, among other institutional tenets, an expansive and intrusive penal system which employs drastic disciplinarian power over these social sectors marginalized from labor and financial markets. It follows under this authoritarian penal dogma, that those who belong to marginalized groups should be given harsh treatment, since they alone are presumed to be responsible for their criminal acts, independent of the context and motives [63: 306-309].

Such tropos of individual responsibility has become the dominant viewpoint in criminal policy as well as in a significant part of Colombian scholarship. During the eighties, the sociological perspective, defended by scholars leaning towards a leftist ideology, explained violent acts (political and common), and the crime associated with them, as the result of the high levels of poverty, inequality and exclusion that typified Colombia [See 10, 23: 22]. Starting in the late nineteen eighties, this theoretical model came under fire, particularly on the part of those who advocated analyzing crime and violence from the economic standpoint. According to this latter group of economists - many of them educated in US elite universities during the nineties, the sociological point of view made claims that were not sufficiently backed by empirical data, and which therefore did not provide a realistic picture of the situation. Subsequently, they stressed that the equation: 'the greater the poverty, the greater the crime', is misleading when the pertinent variables are scrutinized.

The rational economic-actor model is commonly applied to these kinds of studies; according to which an individual decides to commit an unlawful act based upon a cost/benefit analysis. Such studies come to the conclusion that the high rates of crime and violence in Colombia are primarily due to the state's weak response (by law enforcement and the criminal justice system) to lawlessness; therefore, these responses should be tougher and/or more efficient, meaning that, the price for crime should go up [See 55: 111; 22: 14, 15].

\section{More of the same: the expansion of the corrections system}

As it has been shown in previous pages, the configuration of the Colombian crime control field, under the spell of authoritarian liberalism and its upgraded version of neoliberalism during the last 25 years, has resulted in the vertiginous increase of the prison population. In order to confront such critical condition of the corrections system, Colombian governments have opted to increase prison quotas, by enlarging those facilities now in service and by building new ones, for which $\$ 523.5$ billion Colombian pesos (approximately \$US242.5 million dollars) were allocated in the national budget between 1998 and 2003, and with which 16,443 new places for prisoners were created (See National Council on Social and Economic PlanningCONPES-2004: 8,12).

Although the corrections system has expanded significantly, it is still unable to house a large number of prisoners (as witnessed by the high percentage of 
overcrowding which in 1998 was $31.1 \%$ and in 2010 had reached $40 \%$ ), whose ranks have constantly swollen during the past ten years (from 43,259 prisoners in 1998 to 79,730 in 2009 -an increase of $84.3 \%$ in just one decade) (See Table 1 and Chart 1).

Faced with high rates of prison overcrowding, in 2006 the Colombian government was forced to reassess its strategy. Under the new plan, 24,731 new places for inmates (3131 in existing facilities and 21,600 in eleven new penitentiaries) were created $[11: 19 ; 12: 6-7]$ at a lower cost. However, the funds allocated for the plan were reduced in $2004^{7}$ since it was felt that it would be cheaper to commission prison construction under public works rather than through concession to private contractors [12: 6-7].

The most questionable aspect of this situation is that the expanded corrections facilities have not alleviated (not even in terms of space) the living conditions of the great majority of inmates; due to the fact that the new places have arrived too late and have been too few to house the multiplying prison population. As of December, 2006, only 5992 new places of which "5046 (84.2\%) were built in existing facilities and the remaining $946(15.8 \%)$ in new complexes included in previous expansion plans (Apartadó in Antioquia) or as part of the Justice and Peace Program (Tierra Alta in Cordoba)" [50: 7]. Additionally, out of the new places created in 2008, 3441 had not been adequately used "due to a lack of requisite foresight, planning, and budgeting to put them in service" (Ibid). Of the nine new prisons planned for 2004, only six were under construction in 2007 and in September of that same year, the average progress on construction was at $4.66 \%$ (Ibid: 8). In the plan's final stage, the Uribe administration promised to construct 10 new prisons that would create 23,000 new inmate places. In March, 2010, President Uribe presided over the opening of two of these prisons (in Yopal and Cúcuta, which added up to 2222 new places) and he promised to finish construction of the others before the end of his term (in August, 2010). ${ }^{8}$

The expanding penitentiary program, which dominates the rhetoric on corrections policy, pushes firmly ahead, despite its inefficiency and detriment to prisoners' basic rights. As Ariza points out [1], in Colombia this program has been dubbed the new penitentiary culture, whose guiding ideological principles and financial backing are provided by the US government, whose main objective is to base the growth of corrections facilities on administrative efficiency. Consequently, instead of endeavoring to ensure inmates' basic rights, such a system strives to enhance the availability of resources and training for prison personnel and to comply with international ISO quality standards (which apparently correspond to market dictated parameters). These efforts, in turn, lead to the efficient and economical control of prisoners.

In light of the foregoing, and in spite of the fact that the Uribe administration promised a sweeping reform of the Colombian corrections system by constructing new prisons and bringing overcrowding down to $0 \%$, the future of Colombia's prisons and their inhabitants is none too promising. Colombia's criminal justice system seems not only to be enraptured by the need to punish, but with the idea that incarceration should rule (for those accused as well as those tried and sentenced) as the means to

\footnotetext{
${ }^{7}$ From Col\$1,456,448 billion pesos (nearly US\$675 million dollars) to Col\$972,293 million pesos (nearly US\$450.5 million dollars) [12: 6-7].

${ }^{8}$ See "Uribe Opens New Prisons in Yopal and Cúcuta", in El Tiempo (01-04-2010).
} 
incapacitate prisoners and extract social revenge on them, instead of collectively rehabilitating and pardoning them. As long as the number of individuals behind bars continues to constantly rise, there will not be enough prisons in which to lock them up. Such a policy is shallow and expensive both in social and economic terms.

What is more, even though the number of prisons may someday be sufficient, they would still be illegitimate and unjust since, given the characteristics of Colombian society, punishment will continue to be heaped upon the poor who are excluded in a disproportionate and vengeful way. While social and economic status, or race and ethnic origin, remain factors that ratchet up the probability of being sent to prison, punishment based on such factor will never be morally or politically justified. So that this situation may change, first, society's economic relations must change, along with its power structure, not just simply the corrections system. Although the latter is a fundamental social institution it alone cannot be changed without also changing the environment wherein it is planted.

Acknowledgments I would like to extend special thanks to Steve Bayless who translated a previous version of this article from Spanish into English, and to Leonardo Martínez who helped me gathering the data included in this paper.

Open Access This article is distributed under the terms of the Creative Commons Attribution 4.0 International License (http://creativecommons.org/licenses/by/4.0/), which permits unrestricted use, distribution, and reproduction in any medium, provided you give appropriate credit to the original author(s) and the source, provide a link to the Creative Commons license, and indicate if changes were made.

\section{References}

1. Ariza, L. (2011). Reformando el infierno: prisión e intervención judicial in Latinoamérica. In L. Ariza \& M. Iturralde (Eds.), Los Muros de la Infamia (pp. 18-108). Bogotá: Estudios CIJUS, Universidad de los Andes.

2. Bonilla, R. (2006). La reforma económica: una apertura concentradora. In F. Leal (Ed.), En la encrucijada. Colombia en el siglo XXI (pp. 423-450). Bogotá: Norma, Ceso, Universidad de los Andes.

3. Cabrera, M. (2007). Desigualdad y pobreza. Portafolio. http://www.portafolio.co/detalle_archivo/MAM2466476. Accessed 23 Dec 2014.

4. Camacho, Á. (2006). De narcos, paracracias y mafias. In F. Leal (Ed.), En la encrucijada. Colombia en el siglo XXI (pp. 387-421). Bogotá: Norma, Ceso, Universidad de los Andes.

5. Cavadino, M., \& Dignan, J. (2006). Penal policy and political economy. Criminology and Criminal Justice, 6(4), 435-456.

6. Colombian Ministry of Justice. (1989). Plan de desarrollo y rehabilitación del sistema penitenciario nacional. Bogotá: Imprenta Nacional de Colombia.

7. Colombian National Police Force (2008). Tablas históricas sobre delitos y contravenciones. Revista Criminalidad 50(1). http://www.policia.gov.co/imagenes_ponal/dijin/revista_criminalidad/vol50_1/ 50108tablas.html. Accessed 23 Dec 2014.

8. Colombian National Police Force (2009). Tablas estadísticas: delitos y contravenciones, 2008. Revista Criminalidad, 51(1). http://www.policia.gov.co/imagenes_ponal/dijin/revista_criminalidad/vol51_1/ 51102tablas.html. Accessed 23 Dec 2014.

9. Colombian National Police Force (2011). Tablas estadísticas: delitos y contravenciones, 2011. Revista Criminalidad, 54(1). http://oasportal.policia.gov.co/imagenes_ponal/dijin/revista_criminalidad/vol54/ tablas.html. Accessed 23 Dec 2014.

10. Comisión Estudios de sobre la Violencia. (1988). Colombia: violencia y democracia. Informe presentado al Ministerio de Gobierno. Bogotá: Universidad Nacional de Colombia, Colciencias. 
11. Consejo Nacional de Planeación Económica y Social -CONPES- (2004). Documento CONPES 3277. Estrategia para la expansión de la oferta nacional de cupos penitenciarios y carcelarios. Bogotá: Departamento Nacional de Planeación.

12. Consejo Nacional de Planeación Económica y Social-CONPES- (2006). Estrategia para la expansión de la oferta nacional de cupos penitinciarios y carcelarios. Seguimiento del Conpes 3277. Bogotá: Departamento Nacional de Planeación.

13. Cortés, F. (2007). Justicia y exclusión. Bogotá: Siglo del Hombre, Instituto de Filosofía de la Universidad de Antioquia.

14. Del Olmo, R. (1995). La función de la pena y el Estado Latinoamericano. InL. González Placencia (Ed.), La expereincia del penitenciarismo contemporáneo: aportes y expectativas (pp. 67-80). MéxicoD.F.: Comisión Nacional de Derechos Humanos.

15. Del Olmo, R. (1998). The state of prison and prisoners in four countries of the Andean region. In R. Weiss $\&$ N. South (Eds.), Comparing prison systems. Toward a comparative and international penology (pp. 115-139). Amsterdam: Gordon and Breach Publishers.

16. Feeley, M., \& Simon, J. (1992). The new penology: notes on the emerging strategy of corrections and its implications. Criminology, 30(4), 449-474.

17. Gaitán, O. L., Ariza, L., Iturralde, M. (2000). Análisis de la situación carcelaria in Colombia: un enfoque cualitativo. Bogotá: Estudios Ocasionales CIJUS-Universidad de los Andes.

18. Garland, D. (1990). Punishment and modern society. A study in social theory. Oxford: Clarendon.

19. Garland, D. (1998). Criminology, crime control, and 'The American Differince'. University of Colorado Law Review, 69, 1137-1162.

20. Garland, D. (2001). The culture of control. Crime and social order in contemporary society. Oxford: Oxford University Press.

21. Garland, D. (2001). Introduction. The meaning of mass imprisonment. Punishment and Society, 3(1), 5-7.

22. Gaviria, A., et al. (2007). Prólogo. In F. Sánchez (Ed.), Las cuentas de la violencia. Ensayos económicos sobre el conflicto y el crimen en Colombia. Bogotá: Universidad de los Andes, Norma.

23. González, F., Bolívar, I., Vásquez, T. (2002). Violencia política in Colombia. De la nación fragmentada a la construcción del Estado. Bogotá: CINEP.

24. Hartmann, M. (2009). La detención preventiva y la reforma procesal penal en Colombia. In C. Riego \& M. Duce (Eds.), Prisión preventiva y reforma procesal penal in América Latina (pp. 213-266). Santiago: CEJA-JSCA.

25. INPEC (1999). Estadísticas 1999. http://www.inpec.gov.co/portal/page/portal/Inpec/Institucion/Estad\% EDsticas/Estadisticas/Estad\%EDsticas. Accessed 1 Sept 2015.

26. INPEC (2000). Estadísticas 2000. http://www.inpec.gov.co/portal/page/portal/Inpec/Institucion/Estad\% EDsticas/Estadisticas/Estad\%EDsticas. Accessed 1 Sept 2015.

27. INPEC (2008). Estadísticas 2008. http://www.inpec.gov.co/portal/page/portal/Inpec/Institucion/Estad\% EDsticas/Estadisticas/Estad\%EDsticas. Accessed 1 Sept 2015.

28. INPEC (2009). Estadísticas 2009. http://www.inpec.gov.co/portal/page/portal/Inpec/Institucion/Estad\% EDsticas/Estadisticas/Estad\%EDsticas. Accessed 1 Sept 2015.

29. INPEC (2010). Estadísticas 2010. http://www.inpec.gov.co/portal/page/portal/Inpec/Institucion/Estad\% EDsticas/Estadisticas/Estad\%EDsticas. Accessed 1 Sept 2015.

30. INPEC (2011). Estadísticas 2011. http://www.inpec.gov.co/portal/page/portal/Inpec/Institucion/Estad\% EDsticas/Estadisticas/Estad\%EDsticas. Accessed 1 Sept 2015.

31. INPEC (2013). Estadísticas 2013. http://www.inpec.gov.co/portal/page/portal/Inpec/Institucion/Estad\% EDsticas/Estadisticas/Estad\%EDsticas. Accessed 1 Sept 2015.

32. INPEC (2014). Estadísticas 2014. http://www.inpec.gov.co/portal/page/portal/Inpec/Institucion/Estad\% EDsticas/Estadisticas/Estad\%EDsticas. Accessed 1 Sept 2015.

33. International Centre for Prison Studies (2014). World Prison Brief. http://www.kcl.ac.uk/depsta/rel/icps/ worldbrief/world brief.html. Accessed 30 Sept 2014.

34. Iturralde, M. (2007). La sociología del castigo de David Garland: el control del crimen in las sociedades modernas tardías. In D. Garland (Ed.), Crimen y castigo en la modernidad tardia (pp. 19-122). Bogotá: Siglo del Hombre, Universidad de los Andes, Pontificia Universidad Javeriana-Instituto Pensar.

35. Iturralde, M. (2008). Emergency penality and authoritarian liberalism. Recent trends in Colombian criminal policy. Theoretical Criminology, 12(3), 377-397.

36. Iturralde, M. (2010). Castigo, liberalismo autoritario y justicia penal de excepción. Bogotá: Siglo del Hombre, Universidad de los Andes, Universidad Javeriana-Instituto Pensar.

37. Iturralde, M. (2010). Democracies without Citizenship: Crime and Punishment in Latin America. New Criminal Law Review, 13(2), 309-332. 
38. Iturralde, M. (2011). Prisiones y castigo en Colombia: la construcción de un orden social excluyente. In L. Ariza \& M. Iturralde (Eds.), Los Muros de la Infamia (pp. 110-194). Bogotá: Estudios CIJUS, Universidad de los Andes.

39. Jiménez, M. (1994). La cárcel en Latinoamérica en las tres últimas décadas. Capítulo Criminológico, 22, 63-80.

40. Lacey, N. (2008). The prisoners' dilemma. Political economy and punishment in contemporary democracies. Cambridge: Cambridge University Press.

41. Lacey, N. (2010). Differentiating among Penal States. British Journal of Sociology, 61(4), 778-794.

42. Lappi-Seppälä, T. (2008). Trust, welfare, and political culture: Explaining difference in national penal policies. In M. Tonry (Ed.), Vol. 37 of crime and justice: a review of research (pp. 313-387). Chicago: The University of Chicago Press.

43. Melossi, D., Sozzo, M., Sparks, R. (Eds.). (2011). Travels of the criminal question: cultural embeddedness and diffusion. Oxford: Hart.

44. Ministry of Defense (2015). Logros de la Política Integral de Seguridad y Defensa para la Prosperidad. http://www.mindefensa.gov.co/irj/go/km/docs/Mindefensa/Documentos/descargas/ estudios\%20sectoriales/info_estadistica/Logros_Sector_Defensa.pdf. Accessed 15 Aug 2015.

45. Nelken, D. (2010). Denouncing the penal state. Criminology and Criminal Justice, 10(4), 331-340.

46. Nelken, D. (Ed.). (2011). Comprative criminal justice and globalization. Farnham: Ashgate.

47. Observatorio Venezolano de Violencia (2013). Informe del OVV, diciembre de 2013. http:// observatoriodeviolencia.org.ve/ws/informe-del-ovv-diciembre-2013-2/. Accessed 30 Sept 2014.

48. Ortíz, R. (2006). La guerrilla mutante. In F. Leal Leal (Ed.), En la encrucijada. Colombia en el siglo XXI (pp. 323-356). Bogotá: Norma, Ceso, Universidad de los Andes.

49. Ossa, C., \& Garay, L. (2002). Colombia: entre la exclusión y el desarrollo. Propuestas para la transición al Estado Social de Derecho. Bogotá: Contraloría General de la Republica, Alfaomega.

50. Pérez, M. \& Morales, A. (2008). La política penitinciaria y carcelaria en Colombia. Bogotá : Contraloría General de la República - Contraloría Delegada para el Sector Defensa, Justicia y Seguridad. Dirección de Estudios Sectoriales. http://www.semana.com/Documintos.aspx?Frase=LA $\% 20$ POL $\%$ c3\% $\%$ dTICA $\%$ 20PINITINCIARIA $\% 20 \mathrm{Y} \% 20$ CARCELARIA $\% 20 I N \% 20$ COLOMBIA\&IdSeccion=0\&Autor= \&Palabra $=$. Accessed 17 June 2014.

51. Rodríguez, C. (2005). Neoliberalism and the Transformation of the State in Latin America. A Comparative Study of Argentina, Brazil and Colombia. Doctoral Dissertation, Department of Sociology. Madison: The University of Wisconsin.

52. Rodríguez, C. (2009). La globalización del Estado de derecho. Bogotá: Universidad de los Andes.

53. Rodríguez, C., \& Uprimny, R. (2006). ¿Justicia para todos o seguridad para el mercado? El neoliberalismo y la reforma judicial in Colombia. In M. García et al. (Eds.), ¿Justicia para todos? Sistema judicial, derechos sociales y democracia in Colombia (pp. 109-146). Norma: Bogotá.

54. Romero, M. (2006). Paramilitares, narcotráfico y contrainsurgencia: una experiencia para no repetir. In F. Leal (Ed.), En la encrucijada. Colombia en el siglo XXI (pp. 357-386). Bogotá: Norma, Ceso, Universidad de los Andes.

55. Sánchez, F., Díaz, A.M., Fornisano, M. (2007). Conflicto, crimen violento y actividad criminal en Colombia: un análisis especial. In F. Sánchez (Ed.), Las cuentas de la violencia (pp. 63-129). Bogotá: Universidad de los Andes, Norma.

56. Santos, B. (2001). Derecho y democracia: la reforma global de la justicia. In B. Santos \& M. García (Eds.), El caleidoscopio de las justicias en Colombia (pp. 151-207). Bogotá: Colciencias, Instituto Colombiano de Antropología, Universidad de Coimbra, Universidad de los Andes, Universidad Nacional de Colombia, Siglo del Hombre.

57. Simon, J. (1997). Governing through crime. In L. Friedman \& G. Fisher (Eds.), The crime conundrum. Essays on criminal justice (pp. 171-189). Boulder: Westview Press.

58. Simon, J. (2007). Governing through crime: How the War on crime transformed American democracy and created a culture of fear. New York: Oxford University Press.

59. Sozzo, M. (2011). Working Paper 03. Transition to democracy and penal policy. The case of Argentina. New York: Straus Institute for the Advanced Study of Law and Justice, New York University.

60. Wacquant, L. (2000). Las cárceles de la miseria. Madrid: Alianza.

61. Wacquant, L. (2001). Deadly symbiosis. When ghetto and prison meet and mesh. Punishment and Society, 5(2), 197-205.

62. Wacquant, L. (2003). Towards a dictatorship over the poor? Notes on the penalization of poverty in Brazil. Punishment and Society, 3(1), 95-133.

63. Wacquant, L. (2009). Punishing the poor: the neoliberal government of social insecurity. Durham: Duke University Press. 
64. Whitman, J.Q. (2003). Harsh justice: criminal punishment and the widening divide between America and Europe. New York: Oxford University Press.

65. World Bank (2007). Global Monitoring Report 2007. Millennium Development Goals. http:// siteresources.worldbank.org/INTGLOMONREP2007/Resources/3413191-1176390231604/1264FINAL-LO-RES.pdf. Accessed 13 June 2014).

66. Young, J. (1999). The exclusive society. Social exclusion, crime and difference in late modernity. London: Sage Publications. 